\title{
NOTE
}

\section{Long-term recording of gastric ulcers in cetaceans stranded on the Galician (NW Spain) coast}

\author{
E. Abollo ${ }^{1}$, A. López ${ }^{2}$, C. Gestal ${ }^{1}$, P. Benavente ${ }^{3}$, S. Pascual ${ }^{1, *}$ \\ ${ }^{1}$ Laboratorio de Parasitología, Facultad de Ciencias del Mar, Universidad de Vigo, Apdo. 874, E-36200 Vigo, Spain \\ ${ }^{2}$ C.E.M.MA Anxeriz, 19, $5^{\circ}$ D. Milladoiro, E-15895 Ames, A Coruña, Spain \\ ${ }^{3}$ C.E.S., Apto. 100, O Grove, E-36980 Pontevedra, Spain
}

\begin{abstract}
Long-term (1990-1996) results of recording gastric ulcers in the common dolphin are presented for the NW Spanish Atlantic coast. The occurrence and abundance of cetacean carcasses (belonging to 10 species) with gastric ulcers are also given and discussed. Ulcerations were detected in $17.2 \%$ of the animals examined, with $15 \%$ for common dolphins and 0 to $29.4 \%$ in other cetacean species. A positive relation was noted between ulcer counts and length and maturity of Delphinus delphis. Clusters of the nematode Anisakis simplex could be seen embedded in the gastric ulcers of 3 common dolphins. It could be concluded that gastric ulcers are non-fatal lesions in cetaceans stranded in NW Spain
\end{abstract}

KEY WORDS: Gastric ulcers - Anisakis simplex - Cetacean carcasses - NW Spain

The Galician coast with an length of $1720 \mathrm{~km}$ is an important area for cetacean strandings. In the past few years, unusual strandings and an increased number of dead marine mammals have been reported along the shores of N and NW Spain (López et al. 1996). Various causes of mortality have been suggested, such as toxic pollutants, bioaggressors, and accidental catches by fishermen (López et al. 1996).

Research interest in long-term studies has significantly increased in the last decade (Van Banning 1987. Malmer 1994). To obtain base-line data providing better insights into long-term disease prevalence fluctuations in wild cetacean stocks, a gross-lesion recording programme was carried out for 6 consecutive years.

Material and methods. Stomachs of 263 cetacean carcasses stranded on the NW Spanish coast were necropsied for macroscopic lesions during 1991-1996. The necropsies were carried out according to standard protocols specific for dissection techniques and tissue

\footnotetext{
- Addressee for correspondence.

E-mail: spascual@setei.uvigo.es
}

sampling in cetacean pathology (Borgsteede 1991). A few stomachs were examined fresh, but most were examined after preservation in buffered formol $10 \%$, $70 \%$ ethyl alcohol plus $5 \%$ glycerine, or after being frozen and stored at $-20^{\circ} \mathrm{C}$ before preservation in alcohol. The date, location, total body length (BL) and sex of each animal were recorded. The reproductive status of cetaceans was roughly assessed on the basis of the estimated length at sexual maturity (Perrin \& Reilly 1984, Bloch et al. 1993, Cordeiro de Almeida e Silva 1996). Stomachs dissected from each carcass were cut open, cleaned and the stomach wall examined under stereomicroscopy. The presence or absence of ulcerative lesions in the 3 stomach chambers (cardiac, fundic and pyloric) was noted.

Stomach contents were washed into a series of sieves (mesh sizes $2.0 \mathrm{~mm}$ and 850, 500, 250, and $100 \mu \mathrm{m}$ ). Parasites were removed from semidigested food items and those associated with ulcerations recovered from the gastric mucosa with forceps for later light (LM) and scanning electron microscopy (SEM) taxonomic identification.

The significance of differences between number of ulcers per animal (UC) and sex, length and maturity of common dolphins Delphinus delphis was tested by Mann Whitney $U$-test, correlation analysis and generalized linear models (GLMs). Because of the highly aggregated distribution of stomach ulcers within the cetacean population, GLMs were used as a current statistical method without recourse to writing specific macros or functions to define the appropriate error structure (Wilson \& Grenfell 1997). Differences with $\mathrm{p}<0.05$ were accepted as statistically significant. The data were processed using the SPSS-PC(+) 6.1.2. statistical software. Because of the small sample size and the fact that an interspecific association between frequency and sample size can arise as an artefact 
(Gregory \& Blackburn 1991), no comparative studies were carried out between different cetacean species.

Results. During the period 1991 to 1996 gastric ulcers were detected in $15 \%$ of the Delphinus delphis and in from 0 to $29.4 \%$ of other cetacean species examined (Table 1). Ulcers were only detected in the wall of the fundic part of the stomach, and had a size ranging from $0.5 \mathrm{~cm}$ diameter to $5 \times 3 \mathrm{~cm}$. A total of 23 common dolphin carcasses had from 1 to 5 ulcers. Clusters of Anisakis simplex (Rudolphi, 1809, det. Krabbe, 1878) at various stages of development $\left(\mathrm{L}_{3}, \mathrm{~L}_{4}\right.$ and adult forms) were found partially embedded in the stomach wall ulcerations of 3 common dolphins. Nine $D$. delphis had scars in the stomach and a single common dolphin presented scars and anisakids attached to ulcers. Although interannual variability was noted (Table 2), ranging from $0 \%$ (1992) to $19.6 \%$ (1996), no trends could be observed.

When UC was analysed according to the sex of Delphinus delphis carcasses, no significant differences could be established $(U=1033.5 ; p>0.05)$. Nevertheless, a positive relation could be noted between $\mathrm{UC}$ and host length [(correlation coefficient $\mathrm{r}=0.205$; $\mathrm{p}<0.05) ; U C=-0.687 B L^{0.005} ; \mathrm{r}^{2}=0.034 ; \mathrm{p}<0.05, \mathrm{~N}=$ 148 and between $U C$ and maturity $(U=1349 ; \mathrm{p}<0.01)$ of the common dolphins.

Discussion. This study has established that a single anisakid nematode species, Anisakis simplex, is associated with stomach wall ulcerations in cetaceans stranded in NW Spain. It could be concluded that in the sampling area, several species of small cetaceans are important final hosts for this nematode, as has been previously suggested by other eco-parasitological studies (Pascual et al. 1996).

Table 1. Distribution of ulcers within cetacean populations stranded on the coast of NW Spain. Abundance is expressed as total number of ulcers in a sample of hosts divided by total number of individuals examined for ulcerations. N: total number of stranded animals found on the Galician coast; No. ex.: number of individuals examined; No. ulc.: number of individuals ulcerated $\%$ Ulc.: percentage of individuals examined with ulcers

\begin{tabular}{|c|c|c|c|c|c|}
\hline Host & $N$ & No. ex. & No. ulc. & $\%$ Ulc. & $\begin{array}{l}\text { Abundance } \\
\text { (mean } \pm \mathrm{SD} \text { ) }\end{array}$ \\
\hline Delphinus delphis & 420 & 153 & 23 & 15 & $0.22 \pm 0.67$ \\
\hline Stenella coeruleoalba & 52 & 20 & 4 & 20 & $0.50 \pm 1.23$ \\
\hline Tursiops truncatus & 95 & 35 & 10 & 28.6 & $0.69 \pm 1.37$ \\
\hline Grampus griseus & 27 & 13 & 0 & 0 & 0 \\
\hline Globicephala melas & 44 & 16 & 3 & 18.7 & $0.53 \pm 1.36$ \\
\hline Phocoena phocoena & 64 & 17 & 5 & 29.4 & $0.29 \pm 0.47$ \\
\hline Kogia breviceps & 2 & 2 & 0 & 0 & 0 \\
\hline Lagenorhynchus acutus & 2 & 2 & 0 & 0 & 0 \\
\hline Physeter macrocephalus & 8 & 1 & 0 & 0 & 0 \\
\hline Ziphius cavirostris & 4 & 3 & 0 & 0 & 0 \\
\hline Total & 716 & 262 & 45 & 17.2 & \\
\hline
\end{tabular}

Table 2. Delphinus delphis. Incidence of ulcers in stranded common dolphins during the period 1991 to 1996. N.: number of stranded animals; No ex: number of individuals examined; No. ulc. number of individuals ulcerated; \% Ulc. percentage of individuals examined with ulcers

\begin{tabular}{|crccc|}
\hline Year & N & No. ex. & No. ulc. & \% Uic. \\
\hline 1991 & 43 & 10 & 1 & 10 \\
1992 & 33 & 13 & 0 & 0 \\
1993 & 61 & 20 & 3 & 15 \\
1994 & 45 & 24 & 3 & 12.5 \\
1995 & 77 & 35 & 6 & 17.1 \\
1996 & 137 & 51 & 10 & 19.6 \\
Total & 420 & 153 & 23 & 15 \\
\hline
\end{tabular}

Stomach wall ulcerations in marine mammals have been reported associated with the presence of different anisakid genera. Nematodes of the genus Contracaecum were reported in cetaceans and pinnipeds by Young \& Lowe (1969), Wilson \& Stockdale (1970), Liu \& Edward (1971), Griner (1974) and Brattey \& Ni (1992), and the genus Phocascaris in Phoca groenlandica in Newfoundland and Labrador by Brattey \& Ni (1992). In porpoises, gastric lesions associated with Anisakis simplex have been reported by Young \& Lowe (1969) and Smith (1989) in Scottish waters, by Baker (1992) and Baker \& Martin (1992) in British waters, by Brosens et al. (1996) in Belgian and German waters and by Clausen \& Andersen (1988) and Herreras et al. (1997) in Danish waters. These lesions have also been reported in bottle-nosed dolphins, pilot whales and common dolphins by Cowan et al. (1986), Baker (1992) and Kuiken et al. (1994). The frequency of the ulcers ranged from $8 \%$ recorded by Clausen \& Andersen (1988) to $67 \%$ recorded by Kuiken et al. (1994). Interspecific and interannual variability in the observed frequencies recorded in this paper lie between the above published values, and may be due to differences in the feeding patterns and the abundance of intermediate hosts for $A$. simplex in the different sampling areas (Baker \& Martin 1992).

The stomach contents of odontocetes stranded on the NW Spanish coast have provided evidence that they take prey which they encounter rather than being selective for particular prey items (González et al. 1994). This may well explain that no sex-related differences in ulcers counts on the stomach wall were found between male and female carcasses

The lesions did not appear to stop the passage of ingesta and no haemorrhages from these ulcerations or perforations into the 
abdominal cavity were observed; it could be concluded that gastric ulcers were non-fatal conditions. Moreover, the scars on the stomachs of Delphinus delphis were probably healed ulcers (Baker \& Martin 1992).

Acknowledgements. The authors are very grateful to many people who reported stranded animals and those who helped by storing or transporting specimens, particularly the staff of the C.E.M.MA. Thanks are also due to Conselleria de Educación e Ordenación Universitaria for providing financial support under Project XUGA 30110 A97

\section{LITERATURE CITED}

Baker JR (1992) Causes of mortality and parasites and incidental lesions in dolphins and whales from British waters. Vet Rec 27:569-572

Baker JR, Martin AR (1992) Causes of mortality and parasites and incidental lesions in harbour porpoises (Phocoena phocoenal from British waters. Vet Rec 20:554-558

Borgsteede F (1991) Parasitological examination. In: Kuiken $T$, Garcia Hartmann M (eds) Proceedings of the First ECS workshop on Cetacean Pathology: dissection techniques and tissue sampling. ECS (European Cetacean Society) Newsletter No. 17, Special issue. Leiden, p 11-16

Bloch D, Lockyer C, Zachhariassen P (1993) Age and growth parameters of the long-finned pilot whale off the Faroe islands. In: Donovan $\mathrm{CH}$, Lockyer $\mathrm{CH}$, Martin AR (eds) Biology of the northern hemisphere pilot whales. International Whaling Commission. Special issue 14. Cambridge, p $163-208$

Brattey J, Ni IH (1992) Ascaridoid nematodes from the stomach of harp seals, Phoca groenlandica, from Newfoundland and Labrador. Can J Fish Aquat Sci 49(5):956-966

Brosens L, Jauniaux T, Siebert U, Benke H, Coignoul F (1996) Observations on the helminths of harbour porpoises (Phocoena phocoena) and common guillemots (Uria aalgae) from the Belgian and German coasts. Vet Rec 14:254-257

Clausen B. Andersen R (1988) Health status of harbour porpolses (Phocoena phocoena) from Danish waters. Int Counc Explor Sea, CM-ICES 1985/N 10

Cordeiro de Almeida e Silva M (1996) Contribuçao para o conhecemento do regime alimentar e da biologia da reproduçao do golfinho comun, Delphinus delphis Linnaeus, 1758, na costa portuguesa. Relatorio de estagio, Dep Zool e Antropol. Lisboa

Cowan DF, Walker WA, Brownell RJ (1986) Research on dolphins. In: Bryden MM, Harrison R (eds) Clarendon Press, Oxford, p 3-23

Editorial responsibility: Murray Dailey,

Gunnison, Colorado, USA
Gónzalez AF, López A, Guerra A, Barreiro A (1994) Diets of marine mammals on the northwestern Spanish Atlantic coast with special reference to Cephalopoda. Fish Res 21 $179-191$

Gregory RD, Blackburn TM (1991) Parasite prevalence and host sample size. Parasitol Today 7(11):316-318

Grıner LA (1974) Some diseases of zoo animals. Adv Vet Comp Med 18:251-271

Herreras MV, Kaarstad SE, Balbuena JA, Kinze CC, Raga JA (1997) Helminth parasites of the digestive tract of the harbour porpoise Phocoena phocoena in Danish waters: a comparative geographical analysis. Dis Aquat Org 28: 163-167

Kuiken T, Simpson CR, Allchin PM, Bennett GA, Codd EA, Harris GJ, Howes S, Kennedy JK, Kirkwood RJ, Law NR, Merret S, Phillips S (1994) Mass mortality of common dolphin (Delphinus delphis) in south west England due to incidental capture in fishing gear Vet Rec 22:81-89

López A, Cendrero O, Pérez C, García-Castrillo G (1996) Mamíferos mariños varados no norte e noroeste Español no 1995. Int Counc Explor Sea, Marine Mammals Committee, CM-ICES $1996 / \mathrm{N}: 9$

Liu SK, Edward AG (1971) Gastric ulcers associated with Contracaecum spp. (Nematoda: Ascaridoidea) in a stellar seal lion and a white pelican. J Wildl Dis 7:266-271

Malmer N (1994) Ecological research at the beginning of the next century. O1kos 71(1):171-176

Pascual S, González A, Arias C, Guerra A (1996) Biotic relationships of Illex coindetii and Todaropsis eblanae (Cephalopoda, Ommustrephidae) in the Northeastern Atlantic: evidence from parasites. Sarsia 81:265-274

Perrin WF, Reilly SB (1984) Reproductive parameters of dolphins and small whales of the family Delphinidae. In: Perrin WF, Brownell Jr, DeMaster DP (eds) Reproduction in whales, dolphins and porpoises. International Whaling Commission. Special issue 6. Cambridge, p 97-134

Smith JW (1989) Ulcers associated with larval Anisakis simplex B (Nematoda: Ascaridoidea) in the forestomach of harbour porpoises Phocoena phocoena (L.). Can J Zool 67 : $2270-2276$

Van Banning P (1987) Long-term recording of some fish diseases using general fishery research of some fish diseases using general fishery research surveys in the south-east part of the North Sea. Dis Aquat Org 3:1-11

Wilson K, Grenfell BT (1997) Generalized linear modelling for parasitologists. Parasitol Today 13:33-38

Wilson TM, Stockdale PH (1970) The harp seal, Pagophilus groenlandicus (Erxleben, 1977). XI. Contracaecum sp. infestation in a harp seal. J Wildl Dis 6:152-154

Young PC, Lowe D (1969) Larval nematodes from fish of the subfamily Anısakinae and gastro-mtestinal lesions in mammals. J Comp Pathol 79:301-313

Submitted: September 27, 1997; Accepted: November 6, 1997 Proofs received from author(s): January 19, 1998 